\title{
Greening the Post-pandemic Recovery in the G20
}

\author{
Edward B. Barbier ${ }^{1}$ (D)
}

Accepted: 8 June 2020 / Published online: 15 June 2020

(c) Springer Nature B.V. 2020

\begin{abstract}
Rebuilding G20 economies after the COVID-19 pandemic requires rethinking what type of economy we need and want in the future. Simply reviving the existing 'brown' economy will exacerbate irreversible climate change and other environmental risks. For G20 economies, investing in a workable and affordable green transition is essential. A good place to start is learning what worked and what did not from previous efforts to green the economic recovery during the 2008-2009 Great Recession, examining the cases of the United States and South Korea. Policies for a sustained economic recovery amount to much more than just short-term fiscal stimulus. Transitioning from fossil fuels to a sustainable low-carbon economy will require long-term commitments (5-10 years) of public spending and pricing reforms. The priorities for public spending include support for private sector green innovation and infrastructure, development of smart grids, transport systems, charging station networks, and sustainable cities. Pricing carbon and pollution, and removing fossil-fuel subsidies, can accelerate the transition, raise revenues for the necessary public investments, and lower the overall cost of the green transition.
\end{abstract}

Keywords Carbon pricing · Clean energy · COVID-19 · G20 economies · Green economy · Green New Deal

\section{Introduction}

The COVID-19 pandemic has caused the worst economic contraction since the Great Depression. According to the International Monetary Fund (IMF), the global economy is expected to decline by $3 \%$ in 2020 , with advanced economics experiencing double that loss (Gopinath 2020). To counteract this economic shock, governments worldwide have already

Edward B. Barbier

Edward.barbier@colostate.edu

1 Department of Economics, Colorado State University, Fort Collins, CO 80523-1771, USA 
spent $\$ 9$ trillion in direct fiscal stimulus, public sector loans, equity injections, guarantees, and other fiscal measures (Battersby et al. 2020). Most of this expenditure- $\$ 8$ trillionhas been by the Group of Twenty (G20) advanced and emerging market economies. ${ }^{1}$ This amounts to $4.5 \%$ of gross domestic product (GDP) on average for the G20. It is anticipated that further spending to stimulate economies will continue through 2020 and into 2021 if not longer (Battersby et al. 2020).

The focus on the immediate public health and economic crises of the pandemic has largely relegated climate and environmental concerns to the background. To date, very little of the $\$ 9$ trillion of fiscal spending during the COVID-19 has been directed towards low-carbon energy and other "green" policies. As noted by Helm (2020, p. 25), "In the very short term, the coronavirus has dominated almost all political and administrative bandwidth, with little time to pursue other environmental priorities." In comparison, during the 2008-2009 Great Recession, the G20 and a handful of other economies allocated nearly $16 \%$ of their total fiscal stimulus to "green investments", such as low-carbon energy, energy efficiency, pollution abatement and materials recycling (Barbier 2010a, 2016a).

But as the economic downturn has deepened, attention has shifted from addressing the immediate crisis to how to "build back better" (UN 2020). There are increasing calls to develop a "greener" fiscal response, in order to ensure that climate goals are not sacrificed (Bozuwa et al. 2020; Hepburn et al. 2020). Others have stressed the need to enact a longer term transition to a sustainable, low-carbon economy, through targeted public spending combined with removal of fossil fuel subsidies and carbon pricing (Barbier 2020; IMF 2020; The Economist 2020). This raises issues as to whether a different "policy mix" is required for short-term (1-2 year) fiscal measures as compared to a medium to long-term (5-10 year) strategy for a recovery leading to a green economic transition, and what is the correct role of price reforms, as opposed to public spending, in this policy mix.

Devising green strategies for the economic recovery is becoming essential. Although global carbon dioxide $\left(\mathrm{CO}_{2}\right)$ emissions have fallen sharply during the pandemic, they have risen by $1 \%$ annually over the past decade as growth in energy use from fossil fuels outpaced the rise of low-carbon sources and activities (Jackson et al. 2019; Peters et al. 2020). The 2020 fall in global $\mathrm{CO}_{2}$ emissions of around 2-7\% over 2019 levels is likely to be temporary, as the world economy recovers (Le Quéré et al. 2020). There is also concern that the pandemic will further undermine the commitment to global action on climate, biodiversity and other environmental issues (UN 2020). Evidence is emerging that the crisis has led to weakening of environmental regulations and their enforcement worldwide, with consequences for environmental quality, pollution and land use change (Helm 2020; Troëng et al. 2020).

The G20 economies are at the center of this concern over how the world economy should recover from the coronavirus. They comprise nearly two-thirds of the world's population and land area, $82 \%$ of GDP and $80 \%$ of global $\mathrm{CO}_{2}$ emissions. $^{2}$ The G20 also dominate the "green race" for environmental competitiveness and innovation in key global industries, such as machinery, motor vehicles, engines and turbines, steam generators, iron and steel, batteries, electricity generation and distribution, and domestic appliances (Fankhauser et al. 2013). Thus, greening the post-pandemic recovery in the G20 will have

\footnotetext{
${ }^{1}$ The members of the G20 include 19 countries (Argentina, Australia, Brazil, Canada, China, France, Germany, India, Indonesia, Italy, Japan, Mexico, Russia, Saudi Arabia, South Africa, South Korea, Turkey, the United Kingdom and the United States), plus the European Union.

${ }^{2}$ From the World Bank's World Development Indicators, http://databank.worldbank.org/data/databases. aspx.
} 
important implications not just domestically but also for the future structure of the world economy, the generation of employment, the distribution of wealth and income, and the mitigation of global climate and other environmental risks. ${ }^{3}$

Finally, any long-term strategy for greening the post-pandemic recovery of G20 economies will have to be affordable. As noted previously, these economies have already spent $\$ 8$ trillion on combatting the health and economic crises, and will continue to do so in the near future. Such high levels of deficit spending cannot continue indefinitely without creating unsustainable levels of national debt, which will be just as dangerous as burdening future generations with an economy that is environmentally unsustainable. How to pay for the green transition must be part of the conversation over policy strategy.

Consequently, there are a number of important research questions concerning what a post-COVID green recovery should look like for G20 countries. Here, I highlight and discuss four:

- What are the lessons learned from the 2008-2009 Great Recession for greening the G20 economic recovery over the long term?

- What pubic investments are important and what pricing reforms, if any, are needed?

- How much would such a long-term strategy cost, and how is it paid for?

- What are the likely implication for employment and the distribution of wealth and income?

This paper examines each of these questions in turn. As will become apparent, they are arranged in terms of increasing difficulty to answer at this stage of the current economic downturn. However, all four questions pose important challenges for research in environmental economics and policy at a critical time for both the world economy and the global climate and environment.

\section{Lessons Learned from the Great Recession}

During the 2008-2009 Great Recession, I was asked by the United Nations Environment Programme (UNEP) to devise their "Global Green New Deal", a plan to lift the world economy out of the crisis. My UNEP report was eventually revised and published to include a review of the green stimulus plans by all G20 countries during the Great Recession, examining what worked and what did not (Barbier 2010a). Since then, I have looked at further progress in green policies in G20 economies, including recent Green New Deal proposals (Barbier 2010b, 2016a, 2019).

Although the economic downturn resulting from the COVID-19 crisis is unlike any other we have experienced in recent history, I believe that there are four important lessons from these previous efforts to green economies.

First, a key distinction must be made between short-term stimulus spending for emergency relief and to jump start an economy that is in a deep recession or contraction, as

\footnotetext{
3 This is not to say that greening the recovery of other economies, especially low and middle-income countries, is not also essential. An important lesson of what worked and what did not during the 2008-2009 Great Recession, is that the package of reforms should be different for major economies, such as the G20, as opposed to low and middle-income economies, given the very different structural features of the latter (Altenberg and Assmann 2017; Barbier 2010a, 2016b; Harrison et al. 2017).
} 
opposed to a longer term transition to a sustainable, low-carbon economy. ${ }^{4}$ In other words, there is a difference between policies that are aimed at reviving the economy we already have, compared to policies that are aimed at building the type of economy we want. These policy objectives are not necessarily mutually exclusive and should be overlapping, but unfortunately in times of crises, there is a tendency to emphasize the former and to ignore the latter.

For example, in the short-term (e.g. 1-2 years), the tendency is to focus on additional spending packages that ignore the consequences for public debt and fail to introduce additional measures such as carbon pricing. As we saw during the Great Recession, such stimulus can and should contain "green" elements, some of which may have longer term beneficial implications for greening the economy. ${ }^{5}$ However, to transition to the type of economy we want-a sustainable, low-carbon economy-we need to adopt additional policies that will set in place that transition, as soon as it is feasible to do so.

Second, in order to implement a longer term policy strategy for a green transition, then policies for a sustained economic recovery amount to much more than just short-term fiscal stimulus. Green structural transformation will require long-term commitments (5-10 years) of targeted public spending and pricing reforms. If the aim is to transition from fossil fuels to a sustainable, low-carbon economy, then public spending should support private sector green innovation and target key infrastructure investments. Pricing carbon and pollution, and removing fossil-fuel subsidies, can accelerate the transition, raise revenues for the necessary public investments, and lower the overall cost of the green transition. In short, public spending alone will not de-carbonize the economy and make it sustainable. There is a need for complementary pricing reforms to transition to a greener economy. Implementing these reforms will provide not just the incentives, but also the finance, for long-term investments in low-carbon energy and for reducing dependence on fossil fuels.

Third, any long-term policy for greening the recovery must not only be workable but affordable. In the Global Green New Deal, I suggested that the targeted public spending required for a sustained green recovery and transition would require expenditure of at least $1 \%$ annually of GDP by G20 economies (Barbier 2010a). I believe that this is still a reasonable price tag, even over 5-10 years. But this cost is still high. Even before the pandemic, I argued that such levels of funding over many years should not be funded through deficit spending (Barbier 2019). Saddling future generations with unsustainable levels of national debt can be just as dangerous as burdening them with an economy that is environmentally unsustainable and raises climate risks. Deficit spending is warranted to boost overall demand for goods and services when unemployment rises, consumers do not spend and private investment is down, which is the case for the sharp global contraction causes by the current health crisis. But as noted in the Introduction, G20 economies have already spent upwards of $\$ 8$ trillion during the pandemic (Battersby et al. 2020). This is again where pricing reforms, such as removal of fossil fuel subsidies and pricing carbon through a tax, can help enormously in paying for the public spending required for greening the recovery.

Finally, for G20 economies, a long-term policy commitment to transition to a sustainable, low-carbon economy makes sense as an industrial strategy (Fankhauser et al. 2013;

\footnotetext{
${ }^{4}$ I am grateful for Jon Strand and Michael Toman for pointing this distinction out to me; e.g., see Strand and Toman (2010). For an ex-post analysis review of the evidence on short versus long-term effects of fiscal stimulus during the Great Recession generally, see Ramey (2019).

5 See, for example, Hepburn et al. (2020), who suggest several priority policies for a green stimulus to ensure that the economic recovery from the pandemic will assist rather than retard progress on climate change.
} 
Table 1 Green stimulus during the 2008-2009 Great Recession. Source: Barbier (2010a, 2016a)

\begin{tabular}{|c|c|c|c|c|c|c|c|}
\hline \multirow[t]{2}{*}{ Economies } & \multicolumn{4}{|c|}{ Green stimulus (US\$ bn) } & \multicolumn{3}{|c|}{ Share $(\%)$ of green stimulus in: } \\
\hline & $\begin{array}{l}\text { Low } \\
\text { carbon } \\
\text { power }^{\mathrm{a}}\end{array}$ & $\begin{array}{l}\text { Energy } \\
\text { efficiency }^{\text {b }}\end{array}$ & Waste, water ${ }^{c}$ & Total & Global total & Fiscal stimulus & $\mathrm{GDP}^{\mathrm{d}}$ \\
\hline China & 1.6 & 182.4 & 34.0 & 218.0 & 41.8 & 33.6 & 3.1 \\
\hline United States & 39.3 & 58.3 & 20.0 & 117.7 & 22.5 & 12.0 & 0.9 \\
\hline South Korea & 30.9 & 15.2 & 13.8 & 59.9 & 11.5 & 78.7 & 5.0 \\
\hline Japan & 14.0 & 29.1 & 0.2 & 43.3 & 8.3 & 6.1 & 1.0 \\
\hline $\begin{array}{l}\text { European } \\
\text { Union }^{\mathrm{e}}\end{array}$ & 13.1 & 9.6 & 0.0 & 22.8 & 4.4 & 58.7 & 0.2 \\
\hline Germany & 0.0 & 13.8 & 0.0 & 13.8 & 2.6 & 13.2 & 0.5 \\
\hline France & 0.9 & 5.1 & 0.2 & 6.2 & 1.2 & 18.2 & 0.3 \\
\hline $\begin{array}{l}\text { United King- } \\
\text { dom }\end{array}$ & 0.9 & 4.9 & 0.1 & 5.8 & 1.1 & 16.3 & 0.3 \\
\hline Canada & 1.1 & 1.4 & 0.3 & 2.8 & 0.5 & 8.7 & 0.2 \\
\hline Italy & 0.0 & 1.3 & 0.0 & 1.3 & 0.3 & 1.3 & 0.1 \\
\hline Total G20 & 105.3 & 330.1 & 78.1 & 513.5 & 98.3 & 17.1 & 0.8 \\
\hline Global total & 107.6 & 335.4 & 79.1 & 522.1 & 100.0 & 15.7 & 0.7 \\
\hline
\end{tabular}

G20 is the Group of 20 countries. The members of the G20 include 19 countries (Argentina, Australia, Brazil, Canada, China, France, Germany, India, Indonesia, Italy, Japan, Mexico, Russia, Saudi Arabia, South Africa, South Korea, Turkey, the UK and the US), plus the European Union

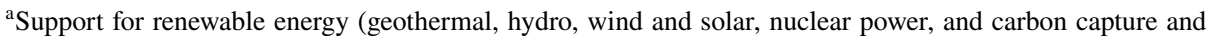
sequestration

${ }^{\mathrm{b}}$ Support for energy conservation in buildings; fuel efficient vehicles; public transport and rail; and improving electrical grid transmission

${ }^{\mathrm{c}}$ Support for water, waste and pollution control, including water conservation, treatment and supply

${ }^{\mathrm{d}}$ Based on 2007 estimated Gross Domestic Product (GDP) in terms of purchasing power parity, from the US Central Intelligence Agency The World Factbook, available at https://www.cia.gov/library/publications/ the-world-factbook/rankorder/2001rank.html

${ }^{\mathrm{e}}$ Only the direct contribution by the European Union is included

Harrison et al. 2017; Rodrik 2014). For example, Fankhauser et al. (2013) maintain that there are several strategic sectors whose transformation is central to the creation of a green economy. These areas include industrial processes, which need to become cleaner and more resource efficient (e.g. iron and steel); sectors that are important for energy efficiency on the supply side (electricity distribution systems) and the demand side (domestic appliances); the energy supply chain for electricity generation and other industrial processes (steam generators; engines and turbines; electric motors and transformers); and car manufacturing (low-emission and electric vehicles) and key components (accumulators, primary cells and batteries). Fankhauser et al. (2013) find that the "green race" to become global competitive leaders in these industries is between eight G20 economies-China, France, Germany, Italy, Japan, South Korea, the United Kingdom and the United States. Thus, a strategy that focuses on policies that promote green innovation in these industries is essential to the overall structural transformation of G20 economies, and in turn, as argued by Rodrik (2014, p. 472), "industrial policies have an indispensable role in putting the global economy on a green growth path." 


\section{National Experiences}

It is instructive to explore further the efforts to stimulate a green recovery during the 2008-2009 Great Recession.

Almost the entire global green stimulus during the Great Recession was by the G20 economies (see Table 1). They devoted nearly $16 \%$ of their total fiscal stimulus to "green investments", such as low-carbon energy, energy efficiency, pollution abatement and materials recycling. In fact, just four economies-China, the United States, South Korea and Japan-accounted for around 85\% of the global green stimulus over 2008-2009.

European G20 economies spent considerably less (Table 1). For example, Germany spent the most on green stimulus ( $\$ 13.8$ billion), followed by France ( $\$ 6.2$ billion), United Kingdom ( $\$ 5.8$ billion) and Italy ( $\$ 1.3$ billion). Together, this spending amounted to just over $5 \%$ of the global green stimulus. The direct contribution of the European Union totaled $\$ 22.8$ billion, which was $4.4 \%$ of the global aggregate. ${ }^{6}$

Over $64 \%$ of the global green stimulus ( $\$ 335$ billion) went to improving energy efficiency, with an aim to create much needed jobs in sectors hard-hit by the Great Recession, such as construction (Table 1). Individual European countries especially allocated much of their stimulus to energy efficiency. For example, the entire green stimulus of Germany and Italy was for energy efficiency, $84 \%$ of the UK's green stimulus and $83 \%$ of France's. In contrast, $42 \%$ of the direct contribution of the European Union was for energy efficiency, and the rest to low-carbon power.

The green stimulus over 2008-2009 by China, South Korea, United States, and Japan amounted to a sizable share of their GDP. However, the type of green stimulus varied considerably across country (Table 1). For example, China invested 3\% of its GDP on green stimulus ( $\$ 218$ billion), but most (84\%) went on energy efficiency. In comparison, South Korea promised to spend 5\% of GDP (\$60 billion) over 2009-2013 as part of a long-term strategy to develop key green industries, such as solar panels, electric cars, wind turbines and high-speed trains, as well as for projects on river restoration and flood control. Only a quarter of its green stimulus went to energy efficiency. The US invested 0.9\% ( $\$ 118$ billion) of its GDP and Japan 1.0\% (\$43 billion) on their respective green stimulus. The US spent half of this stimulus on energy efficiency, but also $\$ 39$ billion on low-carbon power and $\$ 20$ billion on waste and water. Over two-thirds of Japan's green stimulus was for energy efficiency, with the remainder on low-carbon power. However, once the global economic recovery began in 2010, no major green public policy and spending initiative of this scale has been implemented by these four or any other G20 economies.

The contrasting cases of the United States and South Korea are instructive, and help clarify possible lessons for long-term greening of post-pandemic economies today.

The United States spent nearly $\$ 120$ billion on green stimulus during the Great Recession, about $1 \%$ of its GDP, through the American Recovery and Reinvestment Act (ARRA) and smaller programs. Around half of this expenditure went into energy conservation and other short-term energy efficiency investments to quickly boost the economic recovery and generate employment (see Table 1). As the CEA (2016a, p. 13) noted, "A key element in all of the ARRA clean energy-related investments is that while they were designed to

\footnotetext{
6 Two other G20 economies not shown in Table 1, Australia and Saudi Arabian, spent considerably more than European economies on green stimulus over 2008-2009. Australia invested \$9.9 billion (1.3\% of GDP), of which $65 \%$ was on energy efficiency and the remainder on low-carbon power. Saudi Arabia spent $\$ 9.5$ billion (1.7\% of GDP), all on waste, water and pollution control. Sweden invested $\$ 4.2$ billion (1.3\% of GDP) in energy efficiency and Poland spent $\$ 2.1$ billion $(0.3 \%$ of GDP) on low-carbon power.
} 
provide long-term benefits, the allocations focused as much as possible on projects that were 'shovel-ready' and could be deployed relatively quickly, in order to take advantage of resources in the economy that were under-utilized due to the Great Recession." By the end of 2009, 44,200 new jobs were created through energy efficiency, 16,900 jobs in renewable energy generation (mainly installation) and 2200 jobs from other clean energy investments (CEA 2010). From 2009 to 2015, the clean energy-related stimulus programs, most notably energy efficiency, were responsible for 900,000 job-years (full-time jobs over one year) and the training of over 30,000 students for solar careers (CEA 2016a).

The stimulus did help growth of renewable energy (Aldy 2013; CEA 2016a, b; Mundaca and Richter 2015). From 2008 to 2015, the share of non-hydropower renewables in electricity generation increased from 3 to 7\% (CEA 2016b). And while this growth reduced $\mathrm{CO}_{2}$ emissions, the more significant impact came from the slow-down in the economy and switching from coal to natural gas due to the availability of relatively cheap natural gas. In addition, most of the increase in new electricity generation from renewables has been largely due to the large declines in the capital costs of wind and solar installation and generation capacity since 2008 (CEA 2016b; Lazard 2019).

However, there has been no dramatic de-carbonization of the US economy, although $\mathrm{CO}_{2}$ fossil fuel emissions have continued a steady average decline of $0.8 \%$ per year from 2013 to 2018 and are projected decline of $1.7 \%$ in 2019 to 53 billion tonnes (Jackson et al. 2019; Peters et al. 2020). Although renewable and other sources of low-carbon energy continue to grow, so has growth in energy use from fossil fuels. Overall, it is the displacement of coal by natural gas and reduction in overall US electricity demand that is exerting a greater influence on $\mathrm{CO}_{2}$ emissions than the expansion of solar and wind power for electricity generation or the use of hybrid and electric vehicles (Jackson et al. 2019; Peters et al. 2020).

In sum, the 2008-2009 green stimulus in the US did impact job creation and expansion of renewables for several years, but it is no longer helping to de-carbonize the US economy. This is largely attributable to the failure to implement additional incentives, such as pricing carbon, and the "policy void" of any substantial public spending initiatives on the environment since the Great Recession (Barbier 2016a). For example, the green stimulus was originally intended to be combined with a carbon cap-and-trade program, which would have increased substantially renewable energy investment even after the short-term stimulus had expired (Mundaca and Richter 2015). Although the continued growth in renewables and low-emission vehicles is encouraging, without a price on carbon, they are unlikely to displace fossil fuels anytime soon as the major source of energy in the US.

In contrast, South Korea responded to the Great Recession by promoting "low carbon, green growth" as the new long-term development vision of the country. It allocated \$60 billion, or 5\% of Korea's GDP, for its 5-year Green New Deal plan over 2009-2013 (see Table 1). The plan was based around major industrial projects and spending programs, to encourage the substitution of renewable energy sources for conventional fossil fuels, the reduction of resource intensity, and the targeting of green projects through eco-finance, as well as large-scale construction projects such as for Four Rivers Restoration Project to control flooding and water supply and high-speed rail (Barbier 2010a; Jones and Yoo 2012; Mathews 2012). It had the aim of creating 1.5-1.8 million jobs and boosting economic growth through 2020 (Barbier 2010a). Korea's Green New Deal was also the catalyst for a long-term strategy by 2030 to halve energy intensity, reduce by one-quarter the country's dependence on imported fossil fuels, and increase the share of nuclear power and renewables to $40 \%$ of primary energy consumption (Duffield 2014). 
While the Korean Green New Deal did succeed initially in spurring growth and employment, its longer term aims of a green economic transition has fallen short (Choi and Qi 2019; Duffield 2014; Ha and Byrne 2019; Sonnenschein and Mundaca 2016) In the end, South Korea may have spent only \$26 billion on low-carbon energy as part of its Green New Deal (Sonnenschein and Mundaca 2016). It also failed to adopt pricing reforms and other policy incentives to foster renewables, such as phasing out fossil fuel subsidies, enforcing carbon targets and stringent regulatory frameworks. This has slowed the pace of adopting renewables, reducing energy intensity and de-carbonization. For example, South Korea's coal-fueled power plants still account for $43 \%$ of the nation's electricity generation and approximately $25 \%$ of its total carbon emissions; consequently, the country is the world's seventh-largest producer of $\mathrm{CO}_{2}$ emissions (Choi and Qi 2019). Although the goal was to lower energy intensity by $2.5 \%$ per year up to 2030 , it declined by less than $1 \%$ annually from 2006 to 2016 ( $\mathrm{Ha}$ and Byrne 2019). The result is that South Korea's $\mathrm{CO}_{2}$ emissions continue to increase.

Initially, South Korea also saw its industrial strategy tied to green growth (Barbier 2010a; Hwang et al. 2014; Mathews 2012). In addition to the Green New Deal adopted during the Great Recession, the South Korean government established a US \$72.2 million renewable energy fund to attract private investment in solar, wind and hydroelectric power projects. This green industrial policy has had some limited success. By the end of the fiveyear plan, South Korea emerged with a competitive advantage and significant green innovation in basic chemical industries (excluding fertilizer) and special purpose machinery (Fankhauser et al. 2013). As part of its transition to a low-carbon economy, South Korea also plans to develop green technologies to manufacture fuel cells, heat pumps and high efficiency lighting (Hwang et al. 2014). In this regard, one of the successes of the Korean green industrial strategy has less to do with the high-profile infrastructure projects of the Green New Deal but other programs that support green research and development (R\&D) tax credits and allowances, tax reductions for the wages of R\&D workers and accelerated depreciation of capital used for R\&D, which at $0.3 \%$ of GDP has created one of the highest levels of support among major economies (Jones and Yoo 2012).

South Korea did adopt a carbon emissions trading scheme (ETS) in 2015. The scheme covers about $68 \%$ of the country's emissions and is considered a major post-Recession policy for controlling greenhouse gases. The main compliance tools under the ETS involve either directly decreasing $\mathrm{CO}_{2}$ emissions or purchasing emission allowances in the trading market. Unfortunately, the scheme has faced a number of challenges that have limited its effectiveness (ADB 2018; Choi and Qi 2019). The ETS market price has been consistently too low to encourage major emitters in the economy, such as coal-fueled power plants, to actively participate in the carbon emissions-trading market, and thus trading volumes have remained small (Choi and Qi 2019). With a relatively low number of participants and trades, and high uncertainty over the carbon price, many participants have been unwilling to sell unused allowances and have instead held onto them for future compliance periods. Additional allowances released by the government were unsuccessful in stimulating the trade (ADB 2018). As the carbon price remains well below the marginal abatement costs for carbon, especially for coal-fueled power plants, it has been suggested that the Korean government impose a carbon tax, adjust carbon emission quotas, remove fossil fuel subsidies and introduce more stringent regulations both to make the ETS more effective and spur de-carbonization (Choi and Qi 2019; Sonnenschein and Mundaca 2016).

Several important lessons emerge from these national experiences.

First, the green stimulus packages enacted during the Great Recession followed the general recommendation for all fiscal stimulus packages that they be "timely, targeted 
and temporary" (Aldy 2013). The emphasis on energy efficiency spending, and "shovelready" clean energy projects in the US stimulus did impact job creation and expansion of renewables for several years, but provided little long-term support for de-carbonizing the US economy.

Second, even when there is a sustained five-year green investment program enacted, as in the case of South Korea's Green New Deal, expenditure on large-scale infrastructure projects appear to be less important to a sustained growth in renewables, green industrial innovation and development and de-carbonization than more targeted policies, such as public support for green R\&D investment in the economy.

Finally, spending alone will not de-carbonize and create a sustainable economy. There is a need for complementary pricing reforms to transition to clean energy, such as phasing out fossil fuel subsidies and taxing carbon and environmental damages. Implementing these and other pricing reforms will provide the incentives for long-term investments in low-carbon energy, reducing dependence on fossil fuels and creating a more sustainable economy.

\section{Pricing Reforms and Public Investments}

The biggest obstacles to sustaining long-term green structural transformation after the COVID-19 crisis in G20 economies are major market disincentives, especially the underpricing of fossil fuels and market failures that inhibit green innovation. Overcoming these obstacles will involve two steps. First, removing fossil fuel subsidies and employing and carbon taxes to further reduce the social costs of fossil fuel use. Second, allocating any resulting revenue to public support for green innovation and key infrastructure investments.

The most significant deterrent to green structural transformation and innovation in G20 economies is the persistent underpricing of fossil fuels. Current markets for coal, oil and natural gas, as well as for their key products-electricity generation, diesel and gasoline-not only exclude these environmental damages and other impacts, but the prices in these markets are frequently subsidized in G20 economies (Barbier 2016a; Coady et al. 2017, 2019; Gençsü et al. 2019; IEA 2019; IISD 2019b; Parry et al. 2014; Whitley et al. 2018). For example, although coal-fired power plants are the single largest contributor to the growth in global $\mathrm{CO}_{2}$ emissions, annul support for coal by G20 governments includes $\$ 27.6$ billion in public finance, $\$ 15.4$ billion in fiscal support and $\$ 20.9$ billion in stateowned enterprise investments (Gençsü et al. 2019). In addition, there are significant annual subsidies for exploration and exploitation of new reserves of fossil fuels (Bast et al. 2014).

Table 2 depicts various estimates of the underpricing of fossil fuels in G20 economies. They include around $\$ 88$ billion in subsidies in exploration for fossil fuels, which account for on average around $0.2 \%$ of the GDP of G20 economies. In addition, nine emerging market economies of the G20 spend over \$200 billion annually on fossil fuel consumption subsidies, which is about half the global amount of such subsidies, which amounts on average to $1.8 \%$ of their real GDP. The seven major economies of the G20-Canada, France, Germany, Italy, Japan, the United Kingdom and the United States-spend \$100 billion annually on fiscal support and public finance for fossil fuels, or around $0.3 \%$ of their GDP.

Perhaps the most comprehensive estimate of the underpricing of fossil fuels is the IMF's "post-tax" subsidies approach (Coady et al. 2017, 2019; Parry et al. 2014). Their method is based on calculating differences between actual consumer fuel prices and how much consumers would pay if prices fully reflected supply costs plus the taxes need to address environment damages, such as the costs of climate change, local pollution, traffic congestion, 


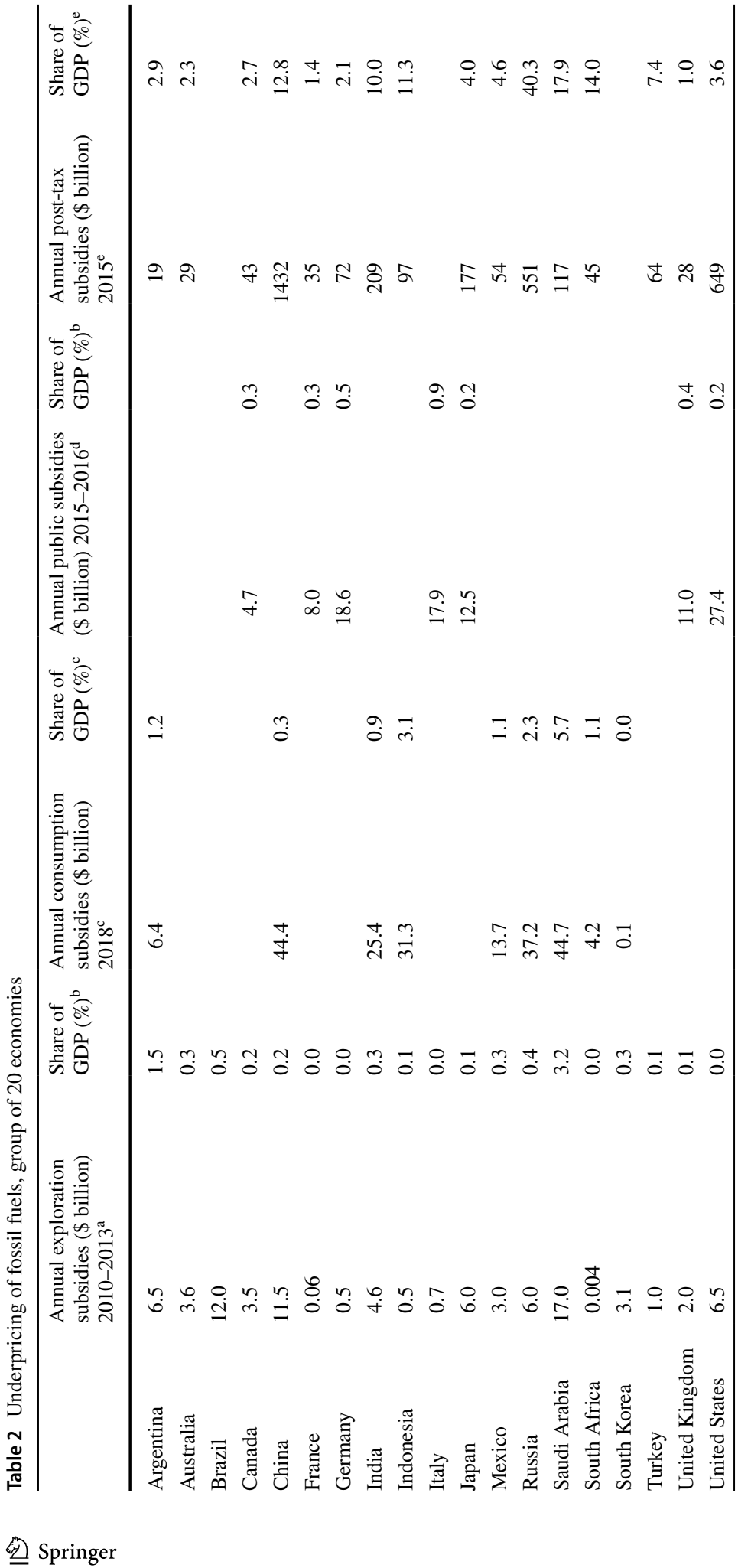




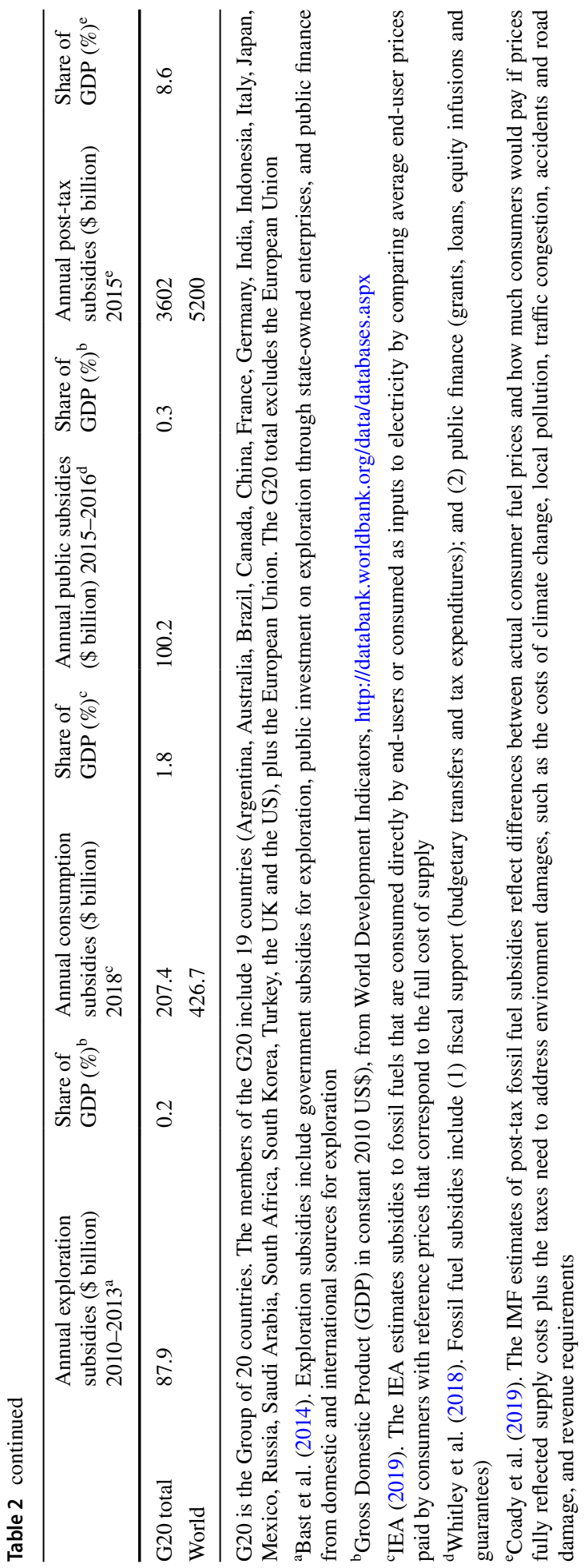


accidents and road damage, and revenue requirements. Globally, the underpricing of fossil fuels continue to be large at $\$ 4.9$ trillion (6.5\% of global GDP) in $2013, \$ 4.7$ trillion $(6.3 \%$ of GDP) in 2015 and $\$ 5.2$ trillion (6.5\% of GDP) in 2017 (Coady et al. 2017, 2019).

Table 2 shows that, in 2015, the post-tax subsidies in 16 major economies amounted to $\$ 3.6$ trillion (8.6\% of GDP on average), which was nearly $70 \%$ of the global total. Underpricing for the costs of climate change accounts for $24 \%$ of the global subsidy in 2015 , local air pollution $48 \%$, broader environmental costs of road fuels $15 \%$, and consumption and supply costs $7 \%$ each (Coady et al. 2019). If fuel prices had been set at fully efficient levels in 2015, estimated global $\mathrm{CO}_{2}$ emissions would have been $28 \%$ lower, fossil fuel air pollution deaths $46 \%$ lower, and fiscal revenues $\$ 2.8$ trillion higher (3.8\% of global GDP) (Coady et al. 2019). Given that G20 economies contribute to $80 \%$ of global $\mathrm{CO}_{2}$ emissions, eliminating the underpricing of fossil fuels in the economies would certainly have a substantial impact on annual global emissions. But the majority of the environmental and economic costs of underpricing fossil fuels-air pollution deaths, morbidity and congestion costs, excessive fiscal spending, and consumption and supply inefficiencies-are not global costs but borne locally (Parry et al. 2014).

The persistent underpricing of fossil fuels also distorts substantially the attractiveness of investing in and using these sources of energy compared to the alternative of clean energy. The costs of renewable energy, especially solar and wind, has declined considerably in recent years, and reached levels of market competitiveness with fossil fuels, most notably in electricity generation (Lazard 2019). As the IISD (2019a, p. 6) notes, "If governments maintain policies that support fossil fuels while the gap between costs on renewables and fossil fuel-based energy grows, taxpayers will be left with a growing fiscal burden to fund the difference." More importantly, if G20 economies continue with public funding of exploration, consumption and other fossil fuel subsidies, as well as fail to price carbon and pollution, they are further retarding the transition to a clean energy economy (Barbier 2010b, 2016a).

Ending the underpricing of fossil fuels in G20 economies would not only remove major market disincentive to green structural transformation and innovation but also raise substantial revenue. As noted above, 16 G20 economies account for around $70 \%$ of the global underpricing of fossil fuels (Table 2). As a rough calculation, applying this percentage to the total fiscal revenues of $\$ 2.8$ trillion gained by efficient pricing (Coady et al. 2019) suggests that the amount for these 15 economies could be around $\$ 1.94$ trillion. This is around $3.7 \%$ of the aggregate 2015 GDP (constant $2010 \$$ ) of these economies. ${ }^{7}$

Although it is unlikely for full efficient pricing to be implemented for fossil fuels in G20 economies, pricing reforms that removed exploration, consumption and other public subsidies, as well as taxing carbon and other pollutants, could nonetheless raise significant revenues over many years. These funds could be used to support green R\&D and innovation and other critical long-term public investments. Even partial pricing reforms could "tip the balance" between fossil fuels and cleaner sources of energy.

For example, IISD (2019a) maintains that a 10-30\% subsidy swap from fossil fuel consumption to investments in energy efficiency and renewable energy electricity generation could substantially improve the transition to a low-carbon economy. Already, some progress along these lines been made in two emerging market G20 economies, India and Indonesia. A study of 26 countries - 10 of which are in the G20 - found that the removal of

\footnotetext{
7 GDP data are from the World Bank's World Development Indicators, http://databank.worldbank.org/data/ databases.aspx.
} 
fossil fuel subsidies on its own reduce greenhouse gas emissions reductions by $6 \%$ on average for each country from 2018 until 2025 (IISD 2019b). ${ }^{8}$

A more ambitious policy combining subsidy removal and carbon taxation could do even more to secure a green economy transition. Take the United States as an example. As Table 2 indicates, there could be $\$ 6.5$ billion in exploration subsidies and $\$ 27$ billion in public support subsidies for fossil fuels that could be re-allocated. ${ }^{9}$ In addition, based on Resources for the Future (RfF)'s E3 Carbon Tax Calculator (Hafstead 2019), a \$40 per tonne tax, rising at $1 \%$ per year above inflation, could reduce cumulative US emissions by 19.5 billion tonnes over 2020-2035 and raise on average $\$ 160$ billion per year in revenues. ${ }^{10}$ The latter amounts to around $0.9 \%$ of the US GDP of $\$ 17.9$ trillion (constant 2010 \$) in 2018. ${ }^{11}$

The upshot is that the combination of fossil fuel subsidy removal and a carbon tax could correct market disincentives as well as provide revenues for 5-10 years of necessary expenditures on public support for green innovation and key infrastructure investments in the United States, and in other G20 economies.

An important impetus for rapid economy-wide innovation is "technology spillovers". These occur when the inventions, designs and technologies resulting from the research and development $(\mathrm{R} \& \mathrm{D})$ activities by one firm or industry spread relatively cheaply and quickly to other firms and industries. These include cross-firm externalities, industry-wide learning, skill development, or agglomeration effects. However, spillovers also undermine the incentives for a private firm or industry to invest in R\&D activities. The private investor bears the full costs of financing $R \& D$, and may improve its own technologies and products as a result, but the investor receives little or no returns from the subsequent spread of these innovations throughout the economy. The consequence is that private firms and industries routinely under-invest in $\mathrm{R} \& \mathrm{D}$, and the result is less economy-wide innovation overall.

As pointed out by Rodrik (2014, p. 470), such market disincentives for investing in innovation "exist in general for all kinds of new technologies, whether they are of the green or dirty kind. However, their novelty, their highly experimental nature, and the substantial risks involved for pioneer entrepreneurs suggest green technologies may be particularly prone to these failures." For example, they are found to be a deterrent to clean energy innovation and development in both emerging market economies and North America (Barbier 2016a; Harrison et al. 2017). Even among the major economies involved in the "green race" to become competitive leaders globally, economy-wide green innovation falls well short of the level necessary to generate structural transformation (Fankhauser et al. 2013).

Moreover, overcoming this disincentive cannot be achieved solely by the use of marketbased incentives to correct inefficient pricing but requires the simultaneous implementation of "technology-push policies", such as research and development (R\&D) subsidies, public investments, protecting intellectual property, and other initiatives (Acemoglu et al. 2012; Goulder 2004). Market-based incentives may reduce pricing distortions that put green

\footnotetext{
8 The 10 G20 economies are Brazil, China, Germany, India, Indonesia, Mexico, Russia, Saudi Arabia, South Africa, and the United States.

9 See Metcalf (2018) for a detailed analysis of the removal of current public support subsidies through tax preferences for US oil and natural gas production.

${ }^{10}$ For further details of the model behind the E3 Carbon Tax Calculator, see Chen et al. (2018). Metcalf (2019) and Metcalf and Stock (2020) explore the macroeconomic implications of imposing a carbon tax in British Columbia and European countries, and find no adverse, and possibly even positive, impacts on GDP and overall employment.

11 GDP data are from the World Bank's World Development Indicators, http://databank.worldbank.org/ data/databases.aspx.
} 
goods and services at a competitive advantage. However, only technology-push policies directly address the tendency of firms and industries to under-invest in green R\&D. Thus, a strategy for a green economic transition must include correcting market disincentives as well as a long-term commitment of public support and funding for private green $R \& D$ and innovation.

But there is good news, too, on the costs of promoting clean energy. Gillingham and Stock (2018) suggest that the high costs today of reducing carbon emissions through some low-carbon technologies could fall quickly if the right policies are adopted.

Expenditures targeted at clean energy research and development will lead to lower costs and wider adoption, as the technology becomes more familiar, innovation spreads, and production scales up. Gillingham and Stock (2018) cite the rapid fall in solar panel costs as one example. There is also a network, or "chicken and egg", effect where increasing demand for a clean-energy technology or product fosters related innovations that lower cost. For example, purchases of electric vehicles will stimulate demand for charging stations, which once installed will reduce the costs of running electric vehicles and further boost demand. This suggests that subsidies for purchasing electric vehicles can kick-start this network effect, but should be phased out once the effect takes hold.

However, public support and investments may also be critical for the removal of other bottlenecks to green structural transformation of G20 economies. For example, one obstacle across all economies is inadequate transmission infrastructure for renewables. This can only be overcome through public investments to design and construct a "smart" electrical grid transmission system that can integrate diffuse and conventional sources of supply. Another is urban development policies that combine municipal planning and transport policies to foster more sustainable cities. Finally, public investment in mass transit systems, both within urban areas and major routes connecting cities has been a long-neglected aspect of public infrastructure development throughout many economies. These and other areas of possible long-term investments for a green recovery are important areas for future research.

Finally, G20 countries with substantial tropical areas, such as Australia, Brazil, India, Indonesia and Mexico, should also consider adopting a "tropical carbon tax" (Barbier et al. 2020). This is a levy on fossil fuels that is invested in natural climate solutions (NCS) aimed at conserving, restoring and improving land management to protect biodiversity and ecosystem services. NCS are a relatively inexpensive way of reducing tropical land use change, which is a major source of greenhouse gas emissions. For example, cost-effective tropical NCS can mitigate $656010^{6}$ tonnes of $\mathrm{CO}_{2} \mathrm{e}$ in the coming decades at less than $\$ 100$ per $10^{3}$ tonnes of $\mathrm{CO}_{2} \mathrm{e}$, which is about one quarter of emissions from all tropical countries (Griscom et al. 2020). Costa Rica and Colombia have already adopted a tropical carbon tax strategy. If a policy similar to Colombia's was put in place by India, it could raise $\$ 916$ million each year to invest in natural habitats that benefit the climate; similarly, Brazil could fund \$217 million annually, Mexico \$197 million and Indonesia \$190 million (Barbier et al. 2020). A more ambitious policy of taxation and revenue allocation could yield nearly $\$ 6.4$ billion each year for natural climate solutions in India, $\$ 1.5$ billion for Brazil, \$1.4 billion for Mexico and \$1.3 billion for Indonesia.

Natural climate solutions, such as reversing deforestation, reforestation, increasing soil carbon levels and enhancing wetlands, are increasingly considered cost-effective investments for mitigating greenhouse gas emissions from land use for temperate G20 economies as well (EASAC 2019; Fargione et al. 2018; Griscom et al. 2017). NCS can provide over one-third of the cost-effective climate mitigation needed by 2030 to stabilize warming to below $2{ }^{\circ} \mathrm{C}$, with one-third of this mitigation costing $\$ 10$ per $10^{3}$ tonnes of $\mathrm{CO}_{2} \mathrm{e}$ or less 
(Griscom et al. 2017). At this cost, the United States could abate 299 million tonnes $\mathrm{CO}_{2} \mathrm{e}$ of greenhouse gas emissions annually through NCS, which would also provide other benefits, such as air and water filtration, flood control, soil conservation and wildlife habitats (Fargione et al. 2018).

To summarize, the lack of public support for private green $R \& D$ and insufficient public investments to overcome other obstacles to long-run green transitions in G20 economies, are serious impediments that need to be addressed. In the current fiscal climate in G20 economies, in which $\$ 8$ trillion has already been spent on combatting the health and economic crises of the pandemic, it may prove difficult to raise additional funds for sustaining additional public investments over the next 5-10 years to "green" the recovery. In recognition of this, there is an urgent need for research into the design of policies, such as a carbon tax, to correct market disincentives as well as generate revenues for longer term essential expenditures on public support for green innovation and key infrastructure investments for a post-coronavirus recovery.

\section{Employment, Income and Wealth}

The final research question-what are the likely implication for employment and the distribution of wealth and income in G20 economies? - is perhaps the most difficult to address at this time. Yet, it may be the most important one, and certainly significant given the skyrocketing unemployment and disproportionate impacts on lower-income households caused by the pandemic.

There is a general presumption that, although the transition to a low-carbon economy will entail some job losses, there will be a net gain in employment overall in major economies. For example, the New Climate Economy report suggests that such a transition will cause low-carbon employment to rise by 65 million people by 2030 , more than offsetting employment losses in declining sectors, leading to a net gain of 37 million jobs (NCE 2018). The ILO (2018) estimates that, limiting climate change to $2{ }^{\circ} \mathrm{C}$, would create approximately 24 million jobs at the loss of approximately 6 million jobs, producing a net increase of 18 million jobs by 2030 .

However, the OECD (2017, p. 11) takes a less sanguine view, arguing that: "Robust empirical evidence of the overall employment effects of ambitious green policies is still lacking. Major transformations of the economy towards green growth are very scarce, and this complicates econometric analysis." Clearly, there is much more work to be done on this crucial research question.

Economic analyses of the possible income and wealth implications of a major transformation to a green economy are even rarer. Structural transformation and technological change towards less-polluting and more resource-efficient economic activities are bound to have significant income and wealth impacts. To some extent, the distribution effects can be offset by policy measures. For example, the Canadian province of British Colombia designed its carbon tax to be revenue-neutral, using any funds raised to reduce corporate and personal income taxes and the burden on low-income households (Metcalf 2019; Yamazaki 2017). Other possible options are to recycle revenues to lessen payroll taxes, pay annual dividends to households, raise the minimum wage, provide payments or retraining for displaced workers, and reduce burdens for vulnerable households affected by the green transition. 
These are important policies to consider in addition to using the revenues from removal of fossil fuel subsidies or imposing taxes on carbon and other environmental damages to fund long-term public support for green innovations and key infrastructure investments. If sufficiently large, the revenues gained from ending the underpricing of fossil fuels could fund both an ambitious strategy of public investments for the green transition as well as a range of policies and programs to offset the distributional consequences of the transition.

For example, the IMF (2020) maintains that containing global warming to $2{ }^{\circ} \mathrm{C}$ or less would require rapidly phasing in measures equivalent to a global tax of at least $\$ 75$ per ton by 2030, whereas the current global average carbon price is $\$ 2$ per ton. According to their calculations, for many countries, a $\$ 75$ per tonne carbon tax would increase gasoline prices by less than the recent collapse in global oil prices during the pandemic. For the United States, even just a $\$ 65$ per tonne tax, rising at $1 \%$ per year above inflation, could reduce cumulative US emissions by 25.6 billion tonnes over 2020-2035 and raise on average $\$ 234$ billion per year in revenues (1.4\% of 2018 real GDP). ${ }^{12}$ These revenues should be sufficient to fund long-term commitments (5-10 years) of public spending on green innovation and key infrastructure and additional expenditures to reduce the burden on low-income households, displaced workers, lowering payroll taxes, and other measures to reduce employment, income and wealth effects.

\section{Conclusion}

Based on input from central bankers and ministries of finance, Hepburn et al. (2020) have identified several priority policies for a green stimulus to ensure that the post-pandemic economic recovery will assist rather than retard progress on climate change: clean physical infrastructure, building efficiency retrofits, investment in education and training, clean energy R\&D and natural climate solutions. These are all important policies to include in stimulus packages, as soon as possible.

However, an important lesson from the green stimulus packages enacted during the 2008-2009 Great Recession is that policies for a sustained economic recovery amount to much more than just short-term fiscal stimulus. Transitioning from fossil fuels to a sustainable, low-carbon economy after the COVID-19 crisis will require long-term commitments (5-10 years) of public spending and pricing reforms. The priorities for public spending are support for private sector green innovation and infrastructure, development of smart grids, transport systems, charging station networks, and sustainable cities. Pricing carbon and pollution, and removing fossil-fuel subsidies, can create the market incentives to accelerate the transition, raise revenues for the necessary public investments, and lower the overall cost of the green transition. Moreover, more ambitious policies to reduce the under-pricing of fossil fuels could raise enough revenues for both public support for green innovation and key infrastructure investments and to mitigate any burdens on low-income households, displaced workers and affected firms, and the unemployed. This suggests a very rich agenda for future research into these important policy issues.

\footnotetext{
12 As before, the carbon tax simulation is calculated using (Hafstead 2019) and the GDP data are from the World Bank's World Development Indicators, http://databank.worldbank.org/data/databases.aspx.
} 
Acknowledgements I am grateful for comments and suggestions provided by Ian Bateman, Jo Burgess and Dieter Helm.

\section{References}

Acemoglu D, Aghion P, Bursztyn L, Hemous D (2012) The environment and directed technical change. Am Econ Rev 102(1):131-166

Aldy J (2013) A preliminary assessment of the American Recovery and Reinvestment Act's clean energy package. Rev Environ Econ Policy 7:136-155

Altenburg T, Assmann C (eds) (2017) Green industrial policy. Concept, policies, country experiences. UN Environment Pogramme and Deutsches Institut für Entwicklungspolitk (DIE), Geneva and Bonn

Asian Development Bank (ADB) (2018) The Korean emissions trading scheme: challenges and emerging opportunities. ADB, Manila

Barbier E (2010a) A global Green New Deal: rethinking the economic recovery. Cambridge University Press, Cambridge and New York

Barbier E (2010b) How is the global Green New Deal going? Nature 464:832-833

Barbier E (2016a) Building the green economy. Can Public Policy 42:S1-S9

Barbier E (2016b) Is green growth relevant for developing countries? Resour Energy Econ 45:178-191

Barbier E (2019) How to make the next Green New Deal work. Nature 565:6

Barbier E (2020) A green post-COVID-19 recovery. In: United Nations Association-UK (UNA-UK). Climate 2020. Witan Media, Painswick, pp 54-56

Barbier E, Lozano R, Rodriguez CM, Troeng S (2020) Adopt a carbon tax to protect tropical countries. Nature 578:213-216

Bast E, Makhijani S, Pickard S, Whitley S (2014) The fossil fuel bailout: G20 subsidies for oil, gas and coal exploration. Overseas Development Institute, London and Oil Change International, Washington, DC

Battersby B, Lam WR, Ture E (2020) Tracking the $\$ 9$ trillion global fiscal support to fight COVID-19, IMFBlog, International Monetary Fund, 20 May 2020. https://blogs.imf.org/2020/05/20/tracking-the-9-trill ion-global-fiscal-support-to-fight-covid-19/

Bozuwa J, Cha JM, Cohen DA, Fleming B, Goodman J, Johnson AE, Kammen DM, NoiseCat JB, Paul M, Patel R, Riofrancos R et al (2020) A green stimulus to rebuild our economy: an open letter and call to action to Members of Congress. Medium, 22 March 2020 https://medium.com/@green_stimulus_now/ a-green-stimulus-to-rebuild-our-economy-1e7030a1d9ee

Chen Y, Goulder L, Hafstead M (2018) The sensitivity of $\mathrm{CO}_{2}$ emissions under a carbon tax to alternative baseline forecasts. Clim Change Econ 9:1840012

Choi Y, Qi C (2019) Is South Korea's emission trading scheme effective? An analysis based on the marginal abatement cost of coal-fueled power plants. Sustainability 11:2504. https://doi.org/10.3390/su110 92504

Coady D, Parry I, Shang B (2017) How large are global fossil fuel subsidies? World Dev 91:11-27

Coady D, Parry I, Le N-P, Shang B (2019) Global fossil fuel subsidies remain large: an update based on country-level estimates. IMF Working Paper WP/19/89, International Monetary Fund, Washington, DC

Council of Economic Advisors (CEA) (2010) American Recovery and Reinvestment Act of 2009: second quarterly report, 13 January 2010. Executive Office of the President of the United States, Washington, DC

Council of Economic Advisors (CEA) (2016a) A retrospective assessment of clean energy investment in the recovery act, February 2016. Executive Office of the President of the United States, Washington, DC

Council of Economic Advisors (CEA) (2016b) The economic record of the Obama Administration addressing climate change, September 2016. Executive Office of the President of the United States, Washington, DC

Duffield J (2014) South Korea's national energy plan 6 years on. Asian Polit Policy 6:433-454

European Academies Science Advisory Council (EASAC) (2019) Forest bioenergy, carbon capture and storage, and carbon dioxide removal: an update. EASAC, Brussels. https:/easac.eu/publications/detai 1s/forest-bioenergy-carbon-capture-and-storage-and-carbon-dioxide-removal-an-update/. Accessed 1 June 2020

Fankhauser S, Bowen A, Calel R, Dechezleprêtre A, Grover D, Rydge J, Sato M (2013) Who will win the green race? In search of environmental competitiveness and innovation. Glob Environ Change 23:902-913 
Fargione J, Bassett S, Boucher T, Bridgham S, Conant R, Cook-Patton S, Ellis P, Falucci A et al (2018) Natural climate solutions for the United States. Sci Adv 4:eaat1869. https://doi.org/10.1126/sciadv.aat18 69

Gençsü I, Whitley S, Roberts L, Beaton C, Chen H, Doukas A, Geddes A, Garsimchuk I, Sanchez L, Suharsono A (2019) G20 coal subsidies: tracking government support to a fading industry. Overseas Development Institute, London

Gillingham K, Stock J (2018) The cost of reducing greenhouse gas emissions. J Econ Perspect 32:53-72

Gopinath G (2020) The great lockdown: worst economic downturn since the great depression, IMFBlog, International Monetary Fund, 14 April 2020. https://blogs.imf.org/2020/04/14/the-great-lockdownworst-economic-downturn-since-the-great-depression/

Goulder L (2004) Induced technological change and climate policy. Pew Center on Global Climate Change, Arlington

Griscom B, Adams J, Ellis P, Houghton R, Lomax G, Miteva D, Schlesinger W, Shoch D et al (2017) Natural climate solutions. Proc Natl Acad Sci 114:11645-11650

Griscom B, Busch J, Cook-Patton S, Ellis P, Funk J, Leavett S, Lomax G, Turner W et al (2020) National mitigation potential from natural climate solutions in the tropics. Philos Trans R Soc B 375:20190126

Ha Y-H, Byrne J (2019) The rise and fall of green growth: Korea's energy sector experiment and its lessons for sustainable energy policy. WIREs Energy Environ 2019:e335. https://doi.org/10.1002/wene.335

Hafstead M (2019) Carbon pricing calculator, resources for the future, 20 September 2019 https://www.rff. org/publications/data-tools/carbon-pricing-calculator/

Harrison A, Martin L, Nataraj S (2017) Green industrial policy in emerging markets. Annu Rev Resour Econ 9:253-274

Helm D (2020) The environmental impacts of the coronavirus. Environ Resour Econ 76:21-38

Hepburn C, O'Callaghan B, Stern N, Stiglitz J, Zenghelis D (2020) Will COVID-19 fiscal recovery packages accelerate or retard progress on climate change? Oxf Rev Econ Policy 36(S1):1-48. https://www. smithschool.ox.ac.uk/publications/wpapers/workingpaper20-02.pdf

Hwang W-S, Oh I, Lee J-D (2014) The impact of Korea's green growth policies on the national economy and environment. BEJ Econ Anal Policy 14(4):1585-1614

International Energy Agency (IEA) (2019). Energy subsidies: tracking the impact of fossil-fuel subsidies. IEA, Paris. https://www.iea.org/topics/energy-subsidies. Accessed 11 May 2020

International Institute for Sustainable Development (IISD) (2019a) Fossil fuel to clean energy subsidy swaps: how to pay for and energy revolution. IISD, Winnipeg

International Institute for Sustainable Development (IISD) (2019b) Raising ambition through fossil fuel subsidy reform: greenhouse gas emissions modelling results from 26 countries. IISD, Winnipeg

International Labor Organization (ILO) (2018) Greening with jobs: world employment social outlook 2018. ILO, Geneva. http://www.ilo.org/wcmsp5/groups/public/—dgreports/—dcomm/—publ/documents/ publication/wcms_628654.pdf. Accessed 28 May 2020

International Monetary Fund (IMF) (2020) Greening the recovery, IMF Special Series on COVID-19, 20 April 2020. https://www.imf.org/ /media/Files/Publications/covid19-special-notes/en-special-serie S-on-covid-19-greening-the-recovery.ashx

Jackson R, Friedlingstein P, Andrew R, Canadell J, Le Quéré C, Peters G (2019) Persistent fossil fuel growth threatens the Paris Agreement and planetary health. Environ Res Lett 14:121001

Jones R, Yoo B (2012) Achieving the "low carbon green growth" vision in Korea. OECD Economics Department Working Papers No. 964. OECD, Paris

Lazard (2019). Lazard's levelized cost of energy analysis-version 13.0, 7 November 2019. https://www. lazard.com/perspective/lcoe2019

Le Quéré C, Jackson R, Jones M, Smith A, Abernathy S, Andrew R, De-Gol A, Willis D, Shan Y, Canadell J, Friedlingstein P, Creutzig F, Peters G (2020) Temporary reduction in daily global $\mathrm{CO}_{2}$ emissions during the COVID-19 forced confinement. Nat Clim Change. Published online 19 May 2020. https:// www.nature.com/articles/s41558-020-0797-x

Mathews J (2012) Green growth strategies-Korean initiatives. Futures 44:761-769

Metcalf GE (2018) The impact of removing tax preferences for US oil and natural gas production: measuring tax subsidies by an equivalent price impact approach. J Assoc Environ Resour Econ 5:1-37

Metcalf G (2019) On the economics of a carbon tax for the United States. Brook Pap Econ Act 49:405-458

Metcalf G, Stock J (2020) Measuring the macroeconomic impact of carbon taxes. AEA Pap Proc 110:101-106

Mundaca L, Richter J (2015) Assessing 'green energy economy' stimulus packages: evidence from the U.S. programs targeting renewable energy. Renew Sustain Energy Rev 42:1174-1186

New Climate Economy (NCE) (2018) Unlocking the inclusive growth story of the 21st century: accelerating climate action in urgent times. https://newclimateeconomy.report/2018/. Accessed 21 May 2020 
Organization for Economic Cooperation and Development (OECD) (2017) Employment implications of green growth: linking jobs, growth, and green policies. OECD, Paris, June 2017. https://fsc-ccf.ca/refer ences/employment-implications-of-green-growth-linking-jobs-growth-and-green-policies-oecd-repor t-for-the-g7-environment-ministers/

Parry I, Heine D, Lis E, Li S (2014) Getting prices right: from principle to practice. International Monetary Fund, Washington, DC

Peters G, Andrew R, Canadell J, Friedlingstein P, Jackson R, Korsbakken J, Le Quéré C, Peregon A (2020) Carbon dioxide emissions continue to grow amidst slowly emerging climate policies. Nat Clim Change 10:2-10

Ramey VA (2019) Ten years after the financial crisis: what have we learned from the renaissance in fiscal research? J Econ Perspect 33:89-114

Rodrik D (2014) Green industrial policy. Oxf Rev Econ Policy 30:469-491

Sonnenschein J, Mundaca L (2016) Decarbonization under green growth strategies? the case of South Korea. J Clean Prod 123:180-193

Strand J, Toman M (2010) Green stimulus, economic recovery, and long-term sustainable development. Policy Research Working Paper No. 5163. World Bank, Washington, DC

The Economist (2020) The covid and climate crises are connected. The Economist, 21 May 2020. https:// www.economist.com/leaders/2020/05/21/the-covid-and-climate-crises-are-connected

Troëng S, Barbier E, Rodriguez C (2020) The COVID-19 pandemic is not a break for nature-let's make sure there is one after the crisis. World Economic Forum, 20 May 2020. https://www.weforum.org/ discom?bobulate $=$ IhYj8O5OhYMHHvoRxXn1dIMKWVwmgLvS\%2BQqXcsdFCX\%2BWg\%2FlA0 rEw1A4FyZ37KjCY5lzml1nJb7YmliRKuEYvHQ\%3D\%3D

United Nations (UN) (2020) Shared responsibility, global solidarity: responding to the socio-economic impacts of COVID-19. UN Secretary General, New York, March 2020. https://www.un.org/sites/un2. un.org/files/sg_report_socio-economic_impact_of_covid19.pdf

Whitley S, Chen H, Doukas A, Gençü I, Garsimchuk I, Touchette L, Worrall L (2018) G7 fossil fuel subsidy scorecard: tracking the phase-out of fiscal support and public finance for oil, gas and coal. Overseas Development Institute, London

Yamazaki A (2017) Jobs and climate policy: evidence from British Columbia's revenue-neutral carbon tax. J Environ Econ Manag 83:197-216

Publisher's Note Springer Nature remains neutral with regard to jurisdictional claims in published maps and institutional affiliations. 